\title{
Effect of Calcium Carbonate Residues from Cement Industries on the Phenolic Composition and Yield of Shiraz Grapes
}

\author{
I.O. Maya-Meraz ${ }^{1}$, R. Pérez-Leal ${ }^{1 *}$, J.J. Ornelas-Paz ${ }^{2}$, J.L. Jacobo-Cuéllar ${ }^{1}$, M.J. Rodríguez-Roque ${ }^{1}$, R.M. Yañez-Muñoz ${ }^{1}$, \\ A. Cabello-Pasini ${ }^{3 *}$ \\ (1) Universidad Autónoma de Chihuahua, Facultad de Ciencias Agrotecnológicas, Área de Fisiología Vegetal y Frutales de \\ Clima Templado, Chih., Chihuahua, México \\ (2) Centro de Investigación en Alimentación y Desarrollo A.C., Laboratorio de Fitoquímicos y Nutrientes, Cuauhtémoc, Chih., \\ México \\ (3) Universidad Autónoma de Baja California, Instituto de Investigaciones Oceanológicas, Ensenada, Baja California, México
}

Submitted publication: April 2019

Accepted for publication: October 2019

Key words: abiotic stress, biotic stress, calcium, grapevines, polyphenols, ripening

\begin{abstract}
Phenolic compounds are secondary metabolites synthesised in response to biotic or abiotic stress in plants. This stress-induced increase in phenolic compound concentrations is generally activated by internal levels of abscisic acid (ABA). The exogenous application of ABA or calcium chloride on grapevines is also known to increase grape yield and alter the phenolic composition of grapes. Residues of cement industries such as calcium carbonates $\left(\mathrm{CaCO}_{3}\right)$ are a safe environmental source of calcium that could be used to induce the synthesis of phenolic compounds and act as a yield promoter in grapes and other crops. Consequently, the objective of this study was to evaluate the effect of cement industries' $\mathrm{CaCO}_{3}$ residues $\left(\mathrm{CaCO}_{3} \mathrm{R}\right)$ on the yield and concentration of phenolic compounds in Shiraz grapes. Thirteen phenolic compounds were identified and quantified by HPLC-DAD. Malvidin-3-O-glucoside was the major anthocyanin found in Shiraz grapes, and its concentration increased by more than $200 \%$ in $\mathrm{CaCO}_{3} \mathrm{R}$-treated vines. Similarly, the concentration of cinnamic acid, the main precursor of phenolic compounds, increased by more than $900 \%$ in grapes treated with $\mathrm{CaCO}_{3}$ residues at harvest time. Finally, catechin, epicatechin and procyanidin $\mathrm{B} 1$ and $\mathrm{B} 2$ increased significantly at harvest time in $\mathrm{CaCO}_{3} \mathrm{R}$-treated grapes relative to the controls. In general, it was found that foliar application of $\mathrm{CaCO}_{3}$ residues from the cement industry at véraison induced an increase in yield, and in the concentration and composition of phenolic compounds in grapes.
\end{abstract}

\section{INTRODUCTION}

Calcium (Ca) is a secondary messenger that triggers environmental adaptive mechanisms in plants as a response to biotic and abiotic stress (Ranty et al., 2016). Biotic stress, resulting from the presence of insects or pathogens in grapevines, for example, triggers jasmonic acid synthesis in the tendrils. Similarly, abiotic stress due to exposure to extreme cold, high UV-B radiation, high levels of metal in the soil, high salinity or drought activates abscisic acid (ABA) synthesis in the leaves and results in stomatal closure (Taurino et al., 2015; Vishwakamara et al., 2017).

It has been demonstrated that $\mathrm{Ca}$ regulates at least three groups of Ca-dependent proteins in Arabidopsis and other plants. Proteins such as calmodulins (CMs), calcineurin B-like proteins (CBLs) and calcium-dependent protein kinases (CDPKs) can play a critical role in cellular signalling cascades. These Ca-dependent proteins operate as sensors and signal transmitters in response to salinity or drought stress, and can induce gene expression that activates ABA synthesis and stomatal closure (Yang et al., 2012; Zou et al., 2015). In vineyards, regulated deficit irrigation is a common practice to induce drought stress in the plant at the onset of ripening or véraison in order to stimulate ABA synthesis and enhance pigment accumulation. However, this irrigation practice commonly reduces grape yield at harvest time (De-la-Hera-Orts et al., 2005; Kyraleou et al., 2017). Recent studies show that foliar ABA application enhances pigment concentration in tomatoes, strawberries, litchis and grapes (Singh et al., 2014; Yamamoto et al., 2015; Jia et al., 2016). It was demonstrated that these ABA applications induce the expression of structural genes and transcription factor genes that activate the phenylpropanoid pathway and anthocyanin synthesis through their effect on the activity of phenylalanine ammonia-lyase (PAL) and chalcone synthase (CHS) enzymes (Ferrandino \& Lovisolo, 2014; Koyama et al., 2014; Villalobos-González et al., 2016). However, exogenous applications in commercial farming

*Corresponding author: E-mail address: acabello@uabc.edu.mx; rleal@uach.mx

Acknowledgements: We would like to thank the Laboratorio de Fitoquimicos y Nutrientes of the Centro de Investigación en Alimentación y Desarrollo A.C of Cd. Cuauhtémoc, Mexico. The $\mathrm{CaCO}_{3}$ residues were supplied by Grupo Cementos Chihuahua. This research was partially supported by CONACyT, Mexico 
are not economically feasible due to the high cost of ABA. Consequently, other studies have explored the use of calcium chloride $\left(\mathrm{CaCl}_{2}\right)$ to increase the synthesis of total phenolic compounds and anthocyanins in plants (Al-Qurashi \& Awad, 2013; Xu et al., 2014; Martins et al., 2018). It has been shown that the use of foliar $\mathrm{CaCO}_{3}$ applications as a source of $\mathrm{Ca}$ increases the total content of phenolic compounds in olives (Squeo et al., 2016). Moreover, $\mathrm{CaCO}_{3}$ application also increase grape yield in commercial vineyards (Sabir et al., 2014).

Overall, phenolic compounds from grapes play a key role in determining wine organoleptic characteristics and quality. Anthocyanins and stilbenes, for example, provide the red or purple coloration in wines, while phenolic acids and flavan-3ols are responsible for astringency and bitterness. In addition to polyphenols, the overall characteristics and balance of the wine are provided by the chemical characteristics of the grapes at harvest. These include the concentration of total soluble solids (TSS), $\mathrm{pH}$, total titratable acidity (TA), organic acid composition, and positive and negative aromas, among others (Nogales-Bueno et al., 2013; Olivares et al., 2017). Thus, the addition of various compounds to improve yield in commercial vineyards must maintain the balance among chemical characteristics and phenolic compounds. It is hypothesised in this study that foliar applications of $\mathrm{CaCO}_{3}$ in grapevines during véraison will increase yield and enhance the accumulation of phenolic compounds in the grapes, without affecting chemical parameters.

Climate change has been associated with high anthropogenic carbon dioxide $\left(\mathrm{CO}_{2}\right)$ emissions into the environment. To mitigate this environmental impact, the cement industries use different processes to capture $\mathrm{CO}_{2}$ emissions and generate residues as $\mathrm{CaCO}_{3}$ (Anbu et al., 2016). These residues could be used as a source of $\mathrm{Ca}$ in commercial farming operations. Particularly, $\mathrm{CaCO}_{3}$ from cement industry residues $\left(\mathrm{CaCO}_{3} \mathrm{R}\right)$ could provide an inexpensive source of $\mathrm{Ca}$ to increase grape yield and polyphenol concentrations in viticulture operations. Consequently, the objective of this study was to evaluate the effect of foliar $\mathrm{CaCO}_{3} \mathrm{R}$ applications on the yield of, and on the total and individual concentrations of phenolic compounds in, Shiraz grapes.

\section{MATERIAL AND METHODS}

\section{Chemicals and solvents}

Malvidin-3-O-glucoside chloride, pelargonidin-3-O-glucoside chloride, cyanidin 3-O-glucoside chloride, cyanidin-3-O-galactoside, gallic acid, trans-cinnamic acid, trans-caftaric acid, protocatechuic acid, trans-resveratrol, $(+)$-catechin, (-)-epicatechin, and procyanidin dimers B1 and B2 standards were used for molecule identification and quantification. All reagents and solvents used were of analytical or HPLC grade, and were purchased from Sigma-Aldrich (St. Louis, Mo, USA), J.T. Baker (Baker-Mallinckrodt Inc, Mexico), and Merck (Merck, Germany).

\section{Study site and treatments}

Experiments were conducted in 2017 at an experimental vineyard $\left(28^{\circ} 25^{\prime} \mathrm{N}\right.$ and $106^{\circ} 51^{\prime} \mathrm{W}, 2010 \mathrm{~m}$ above sea level) owned by the Universidad Autónoma de Chihuahua,
Chihuahua, Mexico. The vineyard consisted of eight-yearold Shiraz vines (1103P rootstock) planted at a $3 \mathrm{~m}$ distance between rows and $1 \mathrm{~m}$ between grapevines. Vines were trained using a Royat system, with rows oriented north-south on sandy loam soils. Drip irrigation was applied from bud break to véraison, and a humidity of $15.6 \%$ was maintained throughout the experimental period. Climatic conditions were monitored at a meteorological station (Quintas Lupitas of Unifrut). Rainfall is frequent during the ripening period at the study site, and the accumulation from the time of $\mathrm{CaCO}_{3} \mathrm{R}$ application until harvest time was $201.4 \mathrm{~mm}$. The average maximum and minimum temperatures were $23.9^{\circ} \mathrm{C}$ and $13.6^{\circ} \mathrm{C}$ respectively.

Calcium carbonate residues (Table 1) from a local cement industry were used as a source of $\mathrm{Ca}$ in the experimental treatments. $\mathrm{A} \mathrm{CaCO}_{3} \mathrm{R}(1 \% \mathrm{w} / \mathrm{w})$ aqueous solution was prepared with tween-20 $\left(0.05 \mathrm{~mL} \mathrm{~L}^{-1}\right)$ as adherent agent. The concentration of the solution was selected after conducting preliminary field tests. The $\mathrm{CaCO}_{3} \mathrm{R}$ solution was applied to the grapevine leaves when clusters reached $>90 \%$ véraison using a backpack piston sprayer at a rate of $1 \mathrm{~L}^{\text {plant }}{ }^{-1}$ (approx. $3.9 \mathrm{~g} \mathrm{Ca} \mathrm{plant}^{-1}$, Table 2). Grape sampling started fifteen days after the $\mathrm{CaCO}_{3} \mathrm{R}$ foliar application. Approximately 200 berries were randomly collected from each treatment once a week from véraison to harvest time.

\section{Foliar elemental analysis}

Forty grapevine leaves were randomly collected once a week before harvest. Leaves were rinsed with deionised water and oven-dried for $72 \mathrm{~h}$ in an oven at $70^{\circ} \mathrm{C}$ to constant weight. The concentration of calcium $(\mathrm{Ca})$, potassium $(\mathrm{K})$, phosphorus $(\mathrm{P})$, magnesium $(\mathrm{Mg})$, manganese $(\mathrm{Mn})$, iron $(\mathrm{Fe})$, copper $(\mathrm{Cu})$ and zinc $(\mathrm{Zn})$ in the leaves was determined using flame atomic absorption spectrometry with oxygen-acetylene flow (PinAAcle 900H, Perkin Elmer, Shelton, CT, USA) (Oliveira et al., 2009). The flame emission measurements were determined at $422.7 \mathrm{~nm}(\mathrm{Ca}), 766.5 \mathrm{~nm}(\mathrm{~K}), 285.2 \mathrm{~nm}(\mathrm{Mg})$, $327 \mathrm{~nm}(\mathrm{Cu}), 372 \mathrm{~nm}(\mathrm{Fe}), 403.1 \mathrm{~nm}(\mathrm{Mn})$ and $213.9 \mathrm{~nm}$ $(\mathrm{Zn})$. Standards (0 to $20 \mathrm{ppm}$ ) were used to calibrate the instrument, and four replicates were analysed per sample.

\section{Grape analysis \\ Chemical analysis}

Fresh berries ( 50 per sample) were randomly collected (four replicates) from each treatment and control to conduct chemical and phenolic analyses. Samples were used to determine tristimulus colour (lightness value $\mathrm{L}^{*}$, colour channels a*

\section{TABLE 1}

Characterisation of $\mathrm{CaCO}_{3}$ residues from cement industries in Chihuahua, Mexico.

\begin{tabular}{lc}
\hline Molecule & Concentration $(\% \mathbf{w} / \mathbf{w})$ \\
\hline Calcium $(\mathrm{Ca})$ & 20.4 \\
Magnesium $(\mathrm{Mg})$ & 0.32 \\
Calcium carbonate $\left(\mathrm{CaCO}_{3}\right)$ & 45.50 \\
Silicon dioxide $\left(\mathrm{SiO}_{2}\right)$ & 33.77 \\
\hline
\end{tabular}


TABLE 2

Phenological stages from dormancy to leaf fall and $\mathrm{CaCO}_{3} \mathrm{R}$ application on Shiraz grapes.

\begin{tabular}{lcc}
\hline Phenological stage & Gregorian day & Degree days $\left({ }^{\circ} \mathbf{C}\right)$ \\
\hline Dormancy & 60 & 108.02 \\
Bud swelling & 73 & 152.44 \\
Bud burst & 78 & 178.80 \\
Beginning of foliar development & 83 & 205.37 \\
Foliar development (>3 leaves unfolded) & 88 & 223.83 \\
Inflorescence clearly visible & 95 & 245.38 \\
Inflorescence fully developed & 99 & 268.74 \\
Flower separating & 110 & 339.03 \\
Flowering & 121 & 410.16 \\
Fruit set & 132 & 473.99 \\
Beginning of véraison & 185 & 990.15 \\
$*$ Véraison (> 90\%) & 198 & 1096.63 \\
Berries ripe for harvest & 242 & 1445.10 \\
Leaves falling & 293 & 1784.27 \\
\hline
\end{tabular}

*Timing of foliar application of $\mathrm{CaCO}_{3} \mathrm{R}$.

and $\mathrm{b}^{*}$ ) using a tabletop colorimeter (CR-300 model, Minolta Co. Ltd, Osaka, Japan). Fruit firmness was determined using a TA-XT2i texture analyser (Texture Technology Corp., Scarsdale, N.Y., USA. and Stable Micro System Ltd, Godalming, UK). The texture analyser was equipped with a $7 \mathrm{~mm}$ diameter stainless steel striker pin that punctured the grape skin at a rate of $10 \mathrm{~mm} \mathrm{~s}^{-1}$. The maximum puncturing force (in Newtons) was determined for 20 berries per treatment (four replicates). Berries were crushed and macerated for $1 \mathrm{~h}$ to evaluate $\mathrm{pH}$ (HANNA Instruments Inc., Woonsocket, USA), TA, TSS and phenolic compounds according to international methods for grapes and wine (OIV, 2017). Total soluble solids in the must were determined using a digital refractometer (ATAGO Co. Ltd., Osaka, Japan), and TA was determined by titration of the sample with $0.1 \mathrm{~N} \mathrm{NaOH}$.

\section{Analysis of polyphenols}

Polyphenols were extracted from the grapes in a dark room with a red safety light. Crushed berries $(\sim 3 \mathrm{~g})$ were mixed with $40 \mathrm{~mL}$ of acetone/water/trifluoroacetic acid (AWTA, 70:29.9:0.1 v/v) and homogenised using an Ultra Turrax (IKA T18) at $1000 \mathrm{rpm}$ for $1 \mathrm{~min}$. The sample was vortexed for $5 \mathrm{~min}$, sonicated on ice for $5 \mathrm{~min}$, and then filtered through a Whatman filter paper No. 4. Material on the filter was further rinsed with $40 \mathrm{~mL}$ AWTA until the tissue was decolorised. The acetone phase was eliminated in a rotavapor $\left(39^{\circ} \mathrm{C}\right)$ and the solution was brought up to $50 \mathrm{~mL}$ with $0.01 \%$ TA. Finally, the extracts were filtered through a $0.45 \mu \mathrm{m}$ membrane filter and stored in borosilicate amber vials for subsequent polyphenol analysis.

Total phenolic compound concentration was determined spectrophotometrically after the Folin-Ciocalteau reactions, and was quantified with gallic acid calibration curves. Individual phenol analysis was performed in an Agilent 1200 series high-performance liquid chromatography (HPLC) system (Agilent, Palo Alto, Ca, USA) with a diode array detector (Ymc Inc. Miliford, Ma, USA) according to standard protocols (Ornelas-Paz et al., 2017). The separation of phenolic compounds was performed with an XDB-C18 column (Agilent, Zorbax eclipse 4.6 x $150 \mathrm{~mm} 5 \mu \mathrm{m}$ ). The column was operated at $30^{\circ} \mathrm{C}$ with mobile phases consisting of $2 \%(\mathrm{v} / \mathrm{v})$ acetic acid (A) and acetonitrile (B). The flow rate was maintained at $1.0 \mathrm{~mL} \mathrm{~min}^{-1}$, with the following gradient: $100 \% \mathrm{~A} / 0 \% \mathrm{~B}$ at $0 \mathrm{~min} ; 93 \% \mathrm{~A} / 7 \%$ B at $12 \mathrm{~min} ; 89 \% \mathrm{~A} / 11 \%$ $\mathrm{B}$ at $20 \mathrm{~min} ; 86 \% \mathrm{~A} / 14 \% \mathrm{~B}$ at $35 \mathrm{~min} ; 84 \% \mathrm{~A} / 16 \% \mathrm{~B}$ at 36 $\mathrm{min} ; 82 \% \mathrm{~A} / 18 \% \mathrm{~B}$ at $41 \mathrm{~min} ; 76 \% \mathrm{~A} / 24 \% \mathrm{~B}$ at $48 \mathrm{~min} ; 70 \%$ $\mathrm{A} / 30 \% \mathrm{~B}$ at $54 \mathrm{~min} ; 65 \% \mathrm{~A} / 35 \% \mathrm{~B}$ at $59 \mathrm{~min} ; 50 \% \mathrm{~A} / 50 \%$ $\mathrm{B}$ at $65 \mathrm{~min} ; 35 \% \mathrm{~A} / 65 \% \mathrm{~B}$ at $70 \mathrm{~min} ; 25 \% \mathrm{~A} / 85 \% \mathrm{~B}$ at 75 min; $15 \% \mathrm{~A} / 85 \% \mathrm{~B}$ at $80 \mathrm{~min} ; 5 \% \mathrm{~A} / 95 \% \mathrm{~B}$ at $85-90 \mathrm{~min}$; and $100 \% \mathrm{~A}$ at $95 \mathrm{~min}$. Polyphenols were monitored with UV-visible spectra for anthocyanins $(\lambda=520 \mathrm{~nm})$, stilbenes $(\lambda=320 \mathrm{~nm})$, phenolic acids $(\lambda=280 \mathrm{~nm})$ and flavan-3-ol groups $(\lambda=280 \mathrm{~nm}$, except catechin, which was monitored at $\lambda=320 \mathrm{~nm}$ ) (Wang et al., 2016). Individual polyphenols were identified and quantified using standards and calibration curves. Compounds were identified using retention time of the peak, the shape of the chromatographic peak and the spectra of the extracted anthocyanins. The retention time and shape of the chromatographic peak was compared to that of specific standards. In addition, internal standards were injected with the samples to verify the compound.

\section{Statistical analysis}

Results were statistically evaluated based on a split-plot in time design. Analysis of variance and a least square means test were used to detect significant differences among 
treatments, and were conducted using SAS System for Windows 9.0 (SAS Institute. Inc. Cary, N.C., USA, 2002) after testing for normality and homoscedasticity of the data. The significance level was set at 0.05 and the experiments were conducted using four replicates.

\section{RESULTS}

Effect of grapevine leaf $\mathrm{CaCO}_{3} \mathrm{R}$ application on yield and chemical characteristics of grapes

Several macro- and micronutrient concentrations in grapevine leaves varied significantly as a result of the $\mathrm{CaCO}_{3} \mathrm{R}$ application relative to the controls (Fig. 1). Thus, the relative concentration of $\mathrm{Ca}$ increased $\sim 25 \%$ in $\mathrm{CaCO}_{3} \mathrm{R}$ treated grapevine leaves compared to the controls (Fig. 1A). In contrast, absolute or relative concentrations of $\mathrm{K}, \mathrm{Mg}$, $\mathrm{Fe}$ and $\mathrm{Mn}$ in $\mathrm{CaCO}_{3} \mathrm{R}$-treated grapevine leaves decreased significantly, but only by up to approximately $10 \%$ relative to the controls (Fig. 1A and 1B). Finally, the concentration of $\mathrm{P}, \mathrm{Cu}$ and $\mathrm{Zn}$ in the leaves did not change significantly in the $\mathrm{CaCO}_{3} \mathrm{R}$-treated vines relative to the controls.

The grape yield and cluster weight of the Shiraz vines also varied as a result of $\mathrm{CaCO}_{3} \mathrm{R}$ application (Fig. 2). While the number of clusters per vine was kept similar between treatments (Fig. 2A), the cluster weight and yield increased significantly, by more than $50 \%$, in the $\mathrm{CaCO}_{3} \mathrm{R}$-treated grapevines relative to the controls (Fig. $2 \mathrm{~B}$ and $2 \mathrm{C}$ ).

In general, there were no significant changes in the chemical composition of the grapes as a result of $\mathrm{CaCO}_{3} \mathrm{R}$ application (Table 3). The percentage of total soluble solids, $\% \mathrm{TA}$ and $\mathrm{pH}$ of the grapes did not vary significantly as a result of $\mathrm{CaCO}_{3} \mathrm{R}$ application relative to the control at harvest time. Similarly, the firmness and colour of the grapes were statistically similar between the control and the treated vines at harvest time.

Influence of pre-harvest $\mathrm{CaCO}_{3} \mathrm{R}$ on the concentration of phenolic compounds in grapes

Total phenolic compounds, stilbenes and anthocyanins

Total phenolic concentration, as well as that of specific phenolic compounds in the berries, varied significantly between the treated and control vines (Table 4). Thus, the total phenolic concentration was approximately threefold greater in the $\mathrm{CaCO}_{3} \mathrm{R}$-treated vines relative to the controls at harvest time, whereas trans-resveratrol did not differ significantly at harvest time between $\mathrm{CaCO}_{3} \mathrm{R}$-treated vines and the controls. The most abundant anthocyanin found in Shiraz grapes was malvidin-3-O-glucoside, which increased nearly threefold at harvest time in the $\mathrm{CaCO}_{3} \mathrm{R}$-treated vines relative to the controls. Similar to malvidin-3-O-glucoside, the mean concentrations of cyanidin-3-O-galactoside, cyanidin-3-O-glucoside and pelargonidin-3-O-glucoside increased two- to threefold in $\mathrm{CaCO}_{3} \mathrm{R}$-treated vines relative to the controls.

\section{Phenolic acids and flavan 3-ols}

At harvest time, the concentration of most phenolic acids and flavan-3-ols increased significantly in the grapes of $\mathrm{CaCO}_{3} \mathrm{R}$-treated vines relative to the controls (Table 5). The concentration of gallic acid in the grapes was 10- to 70fold greater than that of the rest of the phenolic acids. In most cases, the concentration of phenolic acids and flavan3 -ols increased sharply 36 days after $\mathrm{CaCO}_{3} \mathrm{R}$ application. The concentration of the phenolic acid trans-cinnamic acid significantly increased by 12 -fold, while the concentration of caftaric acid increased twofold at harvest time in the berries of $\mathrm{CaCO}_{3} \mathrm{R}$-treated vines relative to those in the controls. In contrast, the concentration of gallic acid remained the same in the treatment and controls at harvest time. The sharp decrease in total and specific phenolic compounds 29 days after $\mathrm{CaCO}_{3} \mathrm{R}$ application coincided with rainfall in the area.

Catechin, epicatechin, and procyanidin B1 and B2 were identified in Shiraz grapes (Table 5). Epicatechin was the major flavan-3-ol in berries, and at harvest time its concentration was twice as high in the $\mathrm{CaCO}_{3} \mathrm{R}$-treated vines than in the controls. Similar to epicatechin, the concentration of catechin and procyanidin B1 was two- to threefold greater at harvest time in the $\mathrm{CaCO}_{3} \mathrm{R}$-treated vines compared to the controls, whereas that of procyanidin $\mathrm{B} 2$ was only $35 \%$ greater in the $\mathrm{CaCO}_{3} \mathrm{R}$-treated vines than in the controls.

Overall, there was a significant increase in the relative
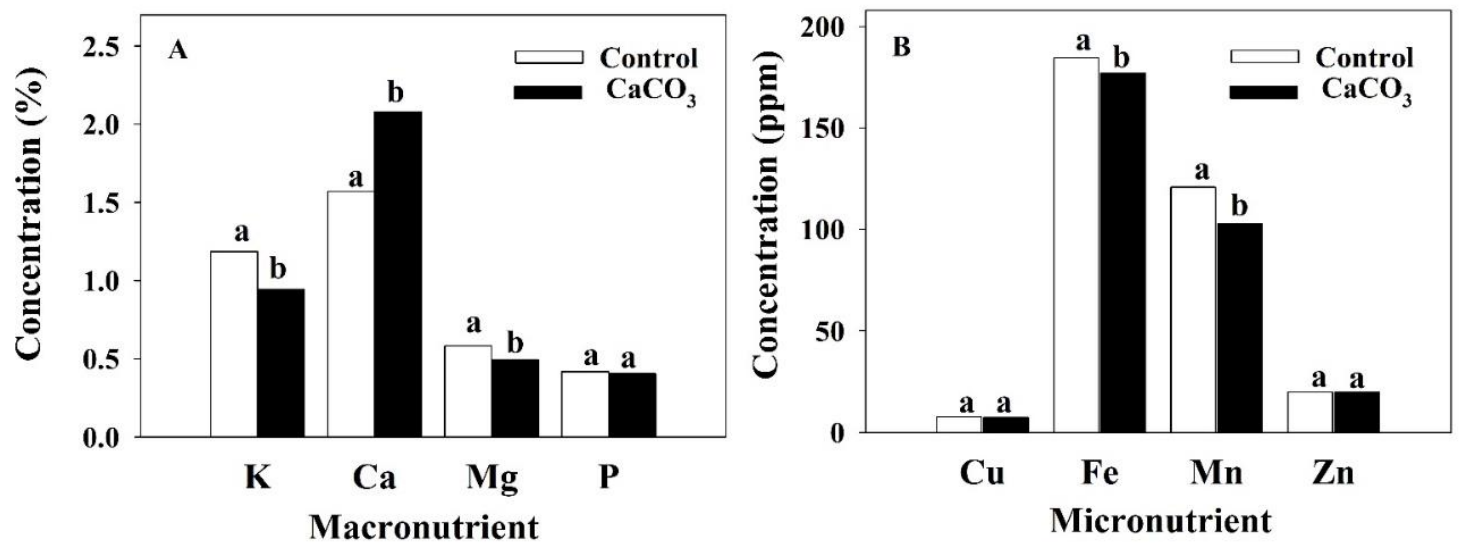

FIGURE 1

Effect of foliar $\mathrm{CaCO}_{3} \mathrm{R}$ application on the relative concentration (\%) of potassium (K), calcium $(\mathrm{Ca})$, magnesium (Mg) and phosphorous $(\mathrm{P})$, and the concentrations (in ppm) of copper $(\mathrm{Cu})$, iron $(\mathrm{Fe})$, manganese $(\mathrm{Mg})$ and zinc $(\mathrm{Zn})$ in the leaves of Shiraz grapes. Different letters above bars indicate statistically significant differences. 


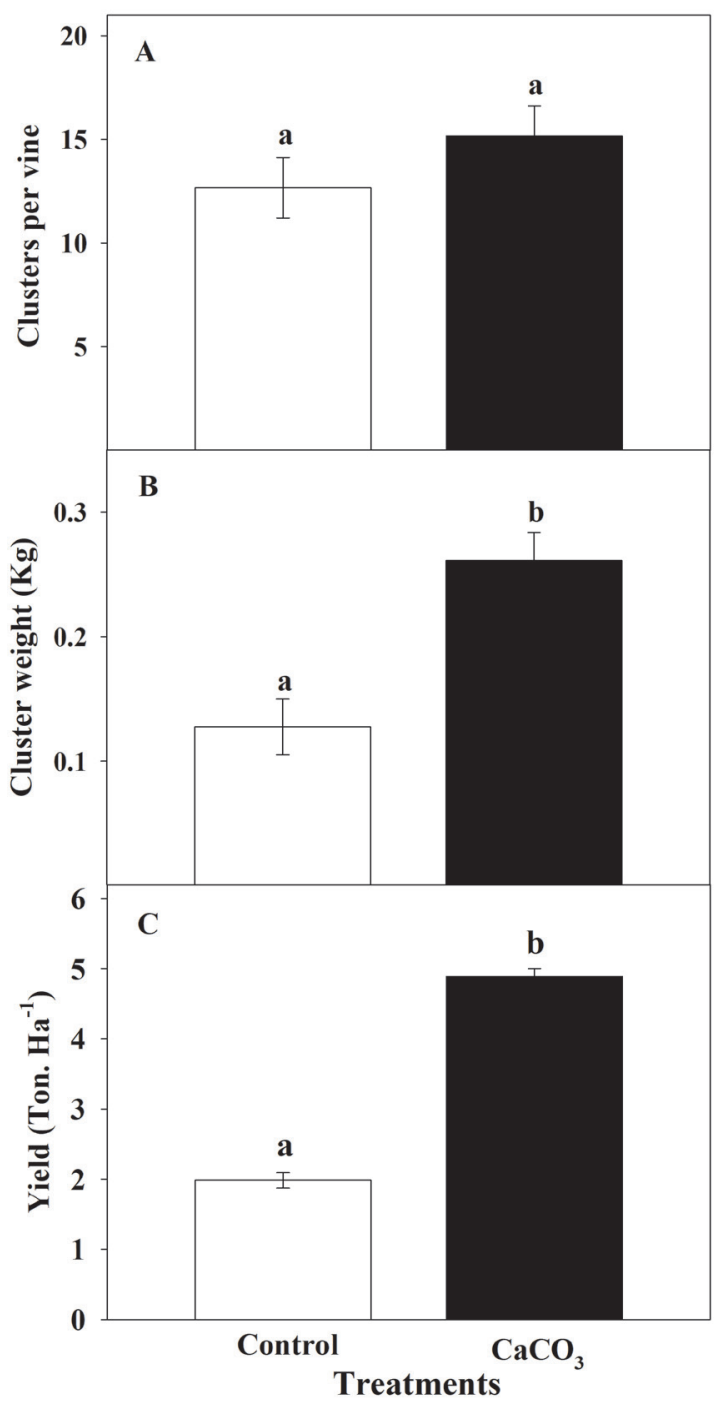

FIGURE 2

Effect of foliar applications of $\mathrm{CaCO}_{3} \mathrm{R}$ on the average number of clusters per grapevine $( \pm \mathrm{SE}$ ), cluster weight and grape yield at harvest time in Shiraz grapes. Different letters above bars indicate statistically significant differences.

concentration of polyphenolic compounds in Shiraz grapes relative to the controls at harvest time. The relative concentration of anthocyanins and flavan-3-ols increased - twofold at harvest time in the berries of $\mathrm{CaCO}_{3} \mathrm{R}-$ treated vines compared to that of the controls. Finally, the relative concentration of stilbene in the berries increased significantly, by $\sim 30 \%$, in the $\mathrm{CaCO}_{3} \mathrm{R}$-treated vines relative to in the controls. In contrast to these polyphenols, there was no detectable variation in the concentration of phenolic acids between treatments and controls at harvest time.

\section{DISCUSSION}

The results of the present study show that foliar $\mathrm{CaCO}_{3} \mathrm{R}$ applications affect macro- and micronutrient concentrations, grape yield, and total and specific polyphenolic concentrations in vine and grape tissue. These results are consistent with the wide impact of calcium on plant physiology found in other studies. Increasing concentration of $\mathrm{Ca}$, for example, increased the biomass of leaves but decreased root dry weight in tobacco plants (López-Lefebre et al., 2001). In contrast, respiration rates and ascorbic acid content in cherries decreased with increasing Ca concentration (Wang et al., 2014). Finally, foliar applications of $\mathrm{CaCl}_{2}$ increased total phenolic content, especially that of anthocyanin, in strawberries (Xu et al., 2014). Clearly, Ca plays a key role in the assimilation of macro- and micronutrients, the activation/ deactivation of specific enzymes, and the expression of genes controlling key metabolic pathways. Similarly, the results of this study suggest that foliar applications of $\mathrm{Ca}$ from $\mathrm{CaCO}_{3}$ residues produced by cement industries impact the overall physiology of wine-producing grapes.

The decrease in tissue $\mathrm{K}, \mathrm{Fe}, \mathrm{Mg}$ and $\mathrm{Mn}$ concentrations in $\mathrm{CaCO}_{3} \mathrm{R}$-treated grape leaves observed in this study is consistent with the results of prior studies. The decrease in tissue $\mathrm{Mg}$ was observed even though there was a small concentration $(0.32 \%)$ of this element in the $\mathrm{CaCO}_{3}$-residues used here. The concentration of $\mathrm{P}, \mathrm{K}$ and $\mathrm{Mg}$ in leaves and fruits of cherry trees, for example, decreased as a result of foliar applications of Ca (Mikiciuk et al., 2015). In addition, the concentration of $\mathrm{Mg}, \mathrm{Na}$ and $\mathrm{P}$ decreased in the leaves and roots of tobacco plants as a result of increasing concentrations of $\mathrm{Ca}$ in the culture media (López-Lefebre 


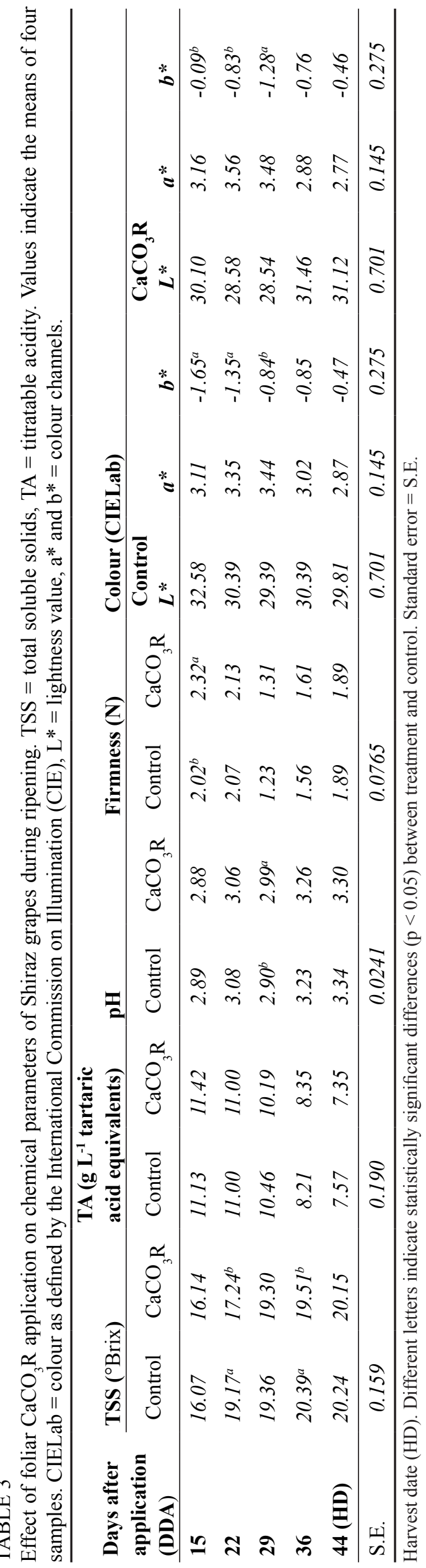

et al., 2001). Changes in the absorption of these ions can affect stomatal aperture (Ruiz et al., 1993; Andrés et al., 2014), the concentration of phenolic compounds, cell wall organisation (Martins et al., 2018), the accumulation of sugars and organic acids in fruit (Prasad et al., 2015), and also overall plant physiology. For example, it has been observed that a disruption in the accumulation of $\mathrm{K}$ in guard cells reduces cell turgidity and the opening of the stoma (López-Lefebre et al., 2001). Similar to K, the increase in $\mathrm{Ca}$ concentration in tissues was shown to reduce stomatal aperture in a number of plants (Ruiz et al., 1993). The Cainduced suppression of stomatal aperture recovers after $\mathrm{Ca}$ concentrations in the xylem decrease. Thus, increasing $\mathrm{Ca}$ concentration via foliar applications might reduce the $\mathrm{K}$ concentration in the leaves and reduce stomatal aperture. Furthermore, the results of the present study suggest that applications of foliar $\mathrm{CaCO}_{3} \mathrm{R}$ could have a similar effect on stomatal closure as that observed in grapevines under restricted irrigation. Moreover, the low concentrations of Fe, $\mathrm{Mg}$ and $\mathrm{Mn}$ found in $\mathrm{CaCO}_{3} \mathrm{R}$-treated grapevine leaves could be related to other physiological processes, given that these elements function as cofactors in a number of key metabolic reactions such as photosynthesis.

The results of the effects of foliar ABA applications on the maturation of grapes are equivocal. On the one hand, some studies have found that the use of ABA and ethephon to enhance phenolic compounds in grapes does not increase grape yield and cluster weight (Peppi et al., 2006; Coelho de Souza-Leaño et al., 2014). However, other studies indicate that foliar ABA application can reduce grape yield and berry size (Alonso et al., 2016). The results of the present study suggest that foliar applications of $\mathrm{CaCO}_{3} \mathrm{R}$ positively affect the yield and cluster weight of Shiraz grapes. This is consistent with the findings in Narince grapes treated with fertilisers containing $\mathrm{CaCO}_{3}$ (Sabir et al., 2014). In contrast, the increase in yield and cluster weight in the present study could be attributed to the fact that treatment with $\mathrm{CaCO}_{3} \mathrm{R}$ reduces the stomatal opening and prevents vine and grape dehydration.

External applications of chemical compounds can affect plant cell physiology and chemical fruit composition. Thus, in some cases, foliar application of ABA can increase the concentration of TSS and anthocyanins in grapes and litchis (Singh et al., 2014; Yamamoto et al., 2015). Other studies, however, have found that the same ABA application showed no differences in TSS, TA, $\mathrm{pH}$ or tristimulus colour relative to controls (Peppi et al., 2006; Alonso et al., 2016; Coelho de Souza-Leaño et al., 2014). The results on the use of exogenous ABA applications are thus equivocal. These chemical parameters are of great interest for winemaking, since they determine the technological maturation of the grapes, potential alcohol content, and the balance between some organoleptic parameters of phenolic compounds in wines (Nogales-Bueno et al., 2013). The increase in TSS and grape colour, however, is likely an artefact of grape dehydration rather than an increase in the synthesis of sugars or anthocyanins (Santiago et al., 2013). The use of $\mathrm{CaCO}_{3} \mathrm{R}$ in the experiment reported in the present study did not affect TSS, TA or $\mathrm{pH}$ in Shiraz grapes. This suggests that the use of $\mathrm{CaCO}_{3} \mathrm{R}$ does not interact with the plant's 
TABLE 4

Mean concentrations of total phenolic compounds, stilbene and anthocyanin in $\mathrm{CaCO}_{3} \mathrm{R}$-treated Shiraz grapes during ripening (mg g $\mathrm{m}^{1}$ dry weight).

\begin{tabular}{rllccc}
\hline \multirow{2}{*}{ Compound and treatment } & \multicolumn{5}{c}{ Days after application (DDA) } \\
\cline { 2 - 6 } & $\mathbf{1 5}$ & $\mathbf{2 2}$ & $\mathbf{2 9}$ & $\mathbf{3 6}$ & $\mathbf{4 4}$ (HD) \\
\hline Total phenolic compounds & & & & & \\
$+\mathrm{CaCO}_{3} \mathrm{R}$ & 5.673 & $5.710^{\mathrm{a}^{*}}$ & 1.855 & $3.340^{\mathrm{a}^{*}}$ & $4.560^{\mathrm{a}^{*}}$ \\
Control & 5.050 & $3.343^{\mathrm{b}}$ & 2.295 & $1.540^{\mathrm{b}}$ & $1.452^{\mathrm{b}}$ \\
S.E. & 0.635 & 0.635 & 0.635 & 0.550 & 0.078
\end{tabular}

Stilbene

Trans-resveratrol

$\begin{array}{rrrrrr}+\mathrm{CaCO}_{3} \mathrm{R} & 0.086 & 0.105 & 0.102 & 0.148^{\mathrm{a}^{*}} & 0.076 \\ \text { Control } & 0.072 & 0.090 & 0.079 & 0.063^{\mathrm{b}} & 0.052 \\ \text { S.E. } & 0.017 & 0.017 & 0.017 & 0.017 & 0.015\end{array}$

Anthocyanins

Malvidin-3-O-glucoside

$\begin{array}{rlllll}+\mathrm{CaCO}_{3} \mathrm{R} & 1.690 & 3.152 & 2.291 & 5.787^{\mathrm{a}^{* *}} & 6.093^{\mathrm{a}^{* *}} \\ \text { Control } & 1.761 & 3.331 & 2.038 & 1.505^{\mathrm{b}} & 2.212^{\mathrm{b}} \\ \text { S.E. } & 0.361 & 0.312 & 0.361 & 0.361 & 0.442\end{array}$

Cyanidin-3-O-galactoside

\begin{tabular}{|c|c|c|c|c|c|}
\hline$+\mathrm{CaCO}_{3} \mathrm{R}$ & 0.518 & 0.629 & 0.519 & $1.160^{\mathrm{a}^{*}}$ & $1.108^{\mathrm{a}^{*}}$ \\
\hline Control & 0.442 & 0.618 & 0.582 & $0.435^{\mathrm{b}}$ & $0.494^{\mathrm{b}}$ \\
\hline S.E. & 0.121 & 0.121 & 0.148 & 0.121 & 0.121 \\
\hline
\end{tabular}

Cyanidin-3-O-glucoside

$\begin{array}{rlllll}+\mathrm{CaCO}_{3} \mathrm{R} & 0.321 & 0.412 & 0.320 & 0.540^{\mathrm{a}^{*}} & 0.621^{\mathrm{a}^{*}} \\ \text { Control } & 0.340 & 0.428 & 0.363 & 0.206^{\mathrm{b}} & 0.283^{\mathrm{b}} \\ \text { S.E. } & 0.050 & 0.061 & 0.050 & 0.050 & 0.050\end{array}$

Pelargonidin-3-O-glucoside

$\begin{array}{rlllll}+\mathrm{CaCO}_{3} \mathrm{R} & 0.204 & 0.299 & 0.157 & 0.477^{\mathrm{a}^{*}} & 0.443^{\mathrm{a}^{*}} \\ \text { Control } & 0.181 & 0.229 & 0.249 & 0.172^{\mathrm{b}} & 0.257^{\mathrm{b}} \\ \text { S.E. } & 0.040 & 0.032 & 0.032 & 0.032 & 0.032\end{array}$

Harvest date (HD). Different letters indicate significant differences between treatments $(*=$ at $p<0.05$ and $* *=p<0.001)$. S.E. $=$ standard error

maturation process, and that the latter is regulated by climatic conditions. However, it is important to highlight that other characteristics, such as the absolute and relative concentrations of phenolic compounds, were positively affected in grapes treated with $\mathrm{CaCO}_{3} \mathrm{R}$.

Exogenous $\mathrm{Ca}$ application is used in the fruit industry to increase fruit firmness and shelf life. While the use of $\mathrm{CaCl}_{2}$ was found to increase these characteristics in El-Bayadi table grapes (Al-Qurashi \& Awad, 2013), leaf ABA application decreased the firmness of Flame Seedless grapes. The use of $\mathrm{CaCO}_{3} \mathrm{R}$ in the present study did not increase Shiraz grape firmness at harvest. Further studies are thus necessary to determine the effect of these chemicals on the firmness and shelf life of different types of grapes. However, since Shiraz grapes are used in the production of wines, it is likely that the application of $\mathrm{CaCO}_{3} \mathrm{R}$ does not play a critical role in the production of wine-producing grapes.

Abscisic acid plays a key role in the biosynthesis of phenols in plants, including grapevines. This acid triggers the biosynthesis of phenolic compounds that filter UV radiation in grapevine leaves (Berli et al., 2011). For example, total phenolic compounds were shown to increase as a result of foliar applications of ABA (Coelho de Souza-Leaño et al., 2014; Yamamoto et al., 2015; Alonso et al., 2016; Wang et al., 2016). Similarly, foliar applications of $50 \mathrm{mM} \mathrm{CaCl}_{2}$ led to an increase in the concentration of total phenolic compounds in grapes and strawberries (Al-Qurashi \& Awad, 2013; Wang et al., 2013, Xu et al., 2014). Furthermore, the use 
TABLE 5

Phenolic acids and flavan-3-ols identified and quantified in $\mathrm{CaCO}_{3} \mathrm{R}$-treated Shiraz grapes and controls during ripening (mg $\mathrm{g}^{-1}$ dry weight).

\begin{tabular}{rllccc}
\hline \multirow{2}{*}{\begin{tabular}{c} 
Compound and treatment \\
\cline { 2 - 6 }
\end{tabular}} & \multicolumn{5}{c}{ Days after application (DDA) } \\
\hline $\begin{array}{r}\text { Phenolic acids } \\
\text { Trans-cinnamic acid } \\
+\mathrm{CaCO}_{3} \mathrm{R}\end{array}$ & 0.021 & 0.030 & 0.041 & 36 & \\
Control & 0.003 & 0.041 & 0.027 & $0.155^{\mathrm{a}^{* *}}$ & $0.169^{\mathrm{a}^{* *}}$ \\
S.E. & 0.006 & 0.006 & 0.006 & $0.004^{\mathrm{b}}$ & $0.014^{\mathrm{b}}$ \\
& & & & 0.006 & 0.006
\end{tabular}

Gallic acid

$\begin{array}{rrrrrr}+\mathrm{CaCO}_{3} \mathrm{R} & 30.558^{\mathrm{a}^{*}} & 23.470^{\mathrm{a}^{*}} & 26.420^{\mathrm{a}^{*}} & 22.145^{\mathrm{a}^{*}} & 4.299 \\ \text { Control } & 13.644^{\mathrm{b}} & 15.439^{\mathrm{b}} & 13.723^{\mathrm{b}} & 5.346^{\mathrm{b}} & 4.541 \\ \text { S.E. } & 3.885 & 3.885 & 3.884 & 2.800 & 3.205\end{array}$

Caftaric acid

\begin{tabular}{|c|c|c|c|c|c|}
\hline$+\mathrm{CaCO}_{3} \mathrm{R}$ & 0.519 & $0.698^{\mathrm{a}^{*}}$ & 0.317 & $0.549^{\mathrm{a}^{*}}$ & $0.473^{\mathrm{a}^{*}}$ \\
\hline Control & 0.631 & $0.383^{\mathrm{b}}$ & 0.459 & $0.319^{\mathrm{b}}$ & $0.240^{\mathrm{b}}$ \\
\hline S.E. & 0.073 & 0.074 & 0.074 & 0.074 & 0.064 \\
\hline
\end{tabular}

Protocatechuic acid

\begin{tabular}{|c|c|c|c|c|c|}
\hline$+\mathrm{CaCO}_{3} \mathrm{R}$ & 0.048 & 0.056 & 0.050 & $0.069^{\mathrm{a}^{*}}$ & $0.061^{\mathrm{a}^{*}}$ \\
\hline Control & 0.044 & 0.044 & 0.039 & $0.034^{\mathrm{b}}$ & $0.036^{\mathrm{b}}$ \\
\hline S.E. & 0.006 & 0.006 & 0.007 & 0.006 & 0.006 \\
\hline
\end{tabular}

Flavan-3-ols

Catechin

$\begin{array}{rlllll}+\mathrm{CaCO}_{3} \mathrm{R} & 0.253 & 0.214 & 0.378 & 0.403^{\mathrm{a}^{*}} & 0.619^{\mathrm{a}^{*}} \\ \text { Control } & 0.187 & 0.188 & 0.387 & 0.145^{\mathrm{b}} & 0.219^{\mathrm{b}} \\ \text { S.E. } & 0.039 & 0.039 & 0.045 & 0.045 & 0.039\end{array}$

Epicatechin

\begin{tabular}{|c|c|c|c|c|c|}
\hline$+\mathrm{CaCO}_{3} \mathrm{R}$ & 1.583 & 1.916 & $1.195^{\mathrm{b} *}$ & 3.998 & $2.639^{\mathrm{a}^{*}}$ \\
\hline Control & 2.234 & 1.838 & $2.342^{\mathrm{a}}$ & 2.905 & $1.270^{\mathrm{b}}$ \\
\hline S.E. & 0.275 & 0.275 & 0.318 & 0.389 & 0.318 \\
\hline
\end{tabular}

Procyanidin B1

\begin{tabular}{|c|c|c|c|c|c|}
\hline$+\mathrm{CaCO}_{3} \mathrm{R}$ & 0.904 & 0.356 & 0.732 & 0.424 & $1.106^{\mathrm{a}}$ \\
\hline Control & 0.908 & 0.228 & 0.886 & 0.454 & $0.421^{\mathrm{b}}$ \\
\hline S.E. & 0.092 & 0.076 & 0.092 & 0.076 & 0.076 \\
\hline
\end{tabular}

Procyanidin B2

\begin{tabular}{|c|c|c|c|c|c|}
\hline$+\mathrm{CaCO}_{3} \mathrm{R}$ & 0.070 & $0.334^{\mathrm{a}^{*}}$ & 0.366 & $0.636^{\mathrm{a}^{*}}$ & $0.779^{\mathrm{a}^{*}}$ \\
\hline Control & 0.032 & $0.033^{\mathrm{b}}$ & 0.284 & $0.379^{\mathrm{b}}$ & $0.501^{\mathrm{b}}$ \\
\hline S.E. & 0.082 & 0.099 & 0.099 & 0.099 & 0.082 \\
\hline
\end{tabular}

Harvest date (HD). Different letters indicate significant differences between treatments $(*=p<0.05$ and $* *=p<0.001)$. S.E. $=$ standard error.

of $\mathrm{CaCO}_{3}$ also increased the concentration of total phenolic compounds in olives (Squeo et al., 2016). In agreement with these studies, the foliar application of approximately $40 \mathrm{mM}$
$\mathrm{CaCO}_{3}$ here also increased phenolic compound concentration in the skins of Syrah grapes. Therefore, the results of the present study agree with the findings of previous studies 
that showed an increase in total phenolic compounds as a result of the foliar application of $\mathrm{Ca}\left(\mathrm{CaCO}_{3}\right.$ or $\left.\mathrm{CaCl}_{2}\right)$. Calcium is a secondary messenger that regulates the groups of Ca-dependent proteins related to the synthesis of ABA and stomatal closure (Yang et al., 2012; Zou et al., 2015; Ranty et al., 2016). Consequently, our results suggest that the use of $\mathrm{CaCO}_{3} \mathrm{R}$ as a source of $\mathrm{Ca}$ could be more economical than the use of ABA or other exogenous compounds to regulate the phenolic concentration in grapes. Additionally, the application of $\mathrm{Ca}$ could be used to regulate the concentration of specific stilbenes, anthocyanins, phenolic acids and flavan-3-ols.

Stilbenes are phytoalexins synthesised as a defence mechanism against biotic stress in plants. The stilbene most commonly studied in Vitis species is trans-resveratrol. The application of a number of chemical compounds is known to affect the accumulation of stilbenes in vine tissue, including in the grapes. Exogenous applications of ABA to vines, for example, increase the concentration of trans-resveratrol in Beihong grapes. This increase was only observed 20 days after ABA application and rapidly decreased thereafter (Wang et al., 2016). Furthermore, applications of $\mathrm{CaCl}_{2}$ to Beihong and Hongbaladuo vines increased trans-resveratrol concentrations in the leaves and berry skins relative to the controls (Wang et al., 2013). In agreement with these studies, foliar applications of $\mathrm{CaCO}_{3} \mathrm{R}$ in the present study resulted in an increase in the concentration of trans-resveratrol as the grapes matured. However, the concentration decreased to levels similar as those measured in the controls at harvest time. The initial increase in trans-resveratrol as a result of $\mathrm{CaCO}_{3} \mathrm{R}$ application might be a direct response to increased $\mathrm{Ca}$ availability. Calcium-dependent proteins, such as CDPKs, CMs and CBLs, trigger the synthesis of ABA (Boss et al., 1996; Yang et al., 2012; Zou et al., 2015; Vandelle et al., 2018). Thus, it is likely that foliar applications of $\mathrm{CaCO}_{3}$ activate some $\mathrm{Ca}$-dependent proteins. In turn, the decrease in trans-resveratrol at harvest time might be the result of substrate competition between stilbene and chalcone synthases, as both use the same substrate. Therefore, the competition for substrate could explain the relationship between the higher concentrations of anthocyanins and lower trans-resveratrol concentrations in $\mathrm{CaCO}_{3} \mathrm{R}$-treated grapes observed at harvest time in the present study.

Anthocyanins in grapes are extracted during maceration and play a key role in the production of red wines. Thus, in the last decade, exogenous substance applications to plants have been used to increase the synthesis of anthocyanins in fruits. Applications of ABA, for example, increased the anthocyanin content in litchis and grapes by 50\% (Singh et al., 2014; Koyama et al., 2014). Similarly, exogenous applications of ABA (approximately $2 \mathrm{mM}$ ) increased the concentration of malvidin-3-O-glucoside and cyanidin in Crimson seedless and Malbec grapes (Coelho de SouzaLeaño et al., 2014; Alonso et al., 2016). External application of $\mathrm{CaCl}_{2}$ was also shown to increase the concentration of cyanidin in strawberries and cherries (Wang et al., 2014; Xu et al., 2014). The presence of pelargonidin-3-O-glucoside and cyanidin-3-O-galactoside is not often reported in the skins of Vitis vinifera grapes. Lately, however, the presence of these molecules has been clearly established in Cabernet sauvignon and Pinot noir grapes grown in high-altitude vineyards (approximately $2500 \mathrm{~m}$; He et al., 2010). It is also likely that the presence of pelargonidin-3-O-glucoside and cyanidin-3-O-galactoside is related to the high elevation of our study site. The present study demonstrates for the first time that foliar $\mathrm{CaCO}_{3} \mathrm{R}$ application increases the concentration of anthocyanins. Thus, this study suggests that exogenous application of $1 \% \mathrm{CaCO}_{3} \mathrm{R}$ is as effective as $\mathrm{ABA}$ or $\mathrm{CaCl}_{2}$ in increasing the synthesis of anthocyanins. This further suggests that there are a number of factors involved in the ripening of grapes, including climatic conditions and the effects of calcium on leaves. Grapevines have different and complex responses to abiotic or biotic stress. Thus, our results suggest that $\mathrm{CaCO}_{3} \mathrm{R}$ might be a source of $\mathrm{Ca}$ that acts as the secondary messenger and activates the response to abiotic stress, and possibly triggers $\mathrm{ABA}$ synthesis or expression in the leaves.

Phenolic acids are the first phenolic compounds synthesised mainly in the tissues of flowers and fruits. The phenylalanine ammonia-lyase enzyme catalyses the conversion of the amino acid phenylalanine to transcinnamic acid, the first phenolic acid (Abdel-Salam \& Hassan, 2015). Foliar application of $\mathrm{ABA}$ and $\mathrm{CaCl}_{2}$ to vines has been shown to change the concentration of phenolic acids in fruits. Thus, the application of ABA led to a decrease in the concentration of gallic acid in the grapes (Alonso et al., 2016). It was also demonstrated that $\mathrm{CaCl}_{2}$ application increased the concentration of trans-cinnamic acid, yet other phenolic acids such as trans-caftaric acid and protocatechuic acid were not affected (Kiselev et al., 2013; Yamamoto et al., 2015; Martins et al., 2018). In agreement with findings obtained with $\mathrm{CaCl}_{2}$ applications, the results of the present study show that foliar applications of $\mathrm{CaCO}_{3} \mathrm{R}$ increase the concentration of trans-cinnamic, acid transcaftaric acid and protocatechuic acid in Shiraz grapes at harvest time. In contrast, gallic acid increases only during early grape maturity. These results suggest that foliar application of $\mathrm{CaCO}_{3} \mathrm{R}$ induces the synthesis of the main phenolic compound precursors.

Flavan-3-ols are responsible for the bitterness and astringency of wines (Kyraleou et al., 2017). Monomeric and oligomeric forms in grapes are known to be affected by ABA application, e.g. the latter resulted in high concentrations of catechin and epicatechin in Yan and Cabernet Sauvignon grapes (Luan et al., 2014). These studies demonstrate that the application of ABA to Cabernet Sauvignon grapes increases the activity of the leucoanthocyanidin reductase, the enzyme responsible for the synthesis of catechins (Lacampagne et al., 2010). Furthermore, foliar application of $\mathrm{CaCl}_{2}$ increased the concentration of epicatechin and procyanidin B1, while leading to a decrease in catechin and procyanidin B2 in Tempranillo and Graciano grapes (Abdel-Salam \& Hassan, 2015). In the present study, the concentration of catechin, epicatechin and procyanidin B1 and B2 increased in grapes treated with $\mathrm{CaCO}_{3} \mathrm{R}$. This suggests that the application of $\mathrm{CaCO}_{3} \mathrm{R}$ increases $\mathrm{ABA}$ expression in leaves and triggers leucoanthocyanidin reductase activity, resulting in an increase in monomeric and oligomeric forms of flavan3 -ols. In general, our results suggest that $\mathrm{CaCO}_{3} \mathrm{R}$ treatment strongly affects the production of all phenolic compounds, 
including anthocyanins, stilbenes, phenolic acids and flavan3-ols. This further suggests that $\mathrm{CaCO}_{3} \mathrm{R}$ could be used to enhance phenolic compounds such as anthocyanins and flavan-3-ols in grapes and others fruits.

\section{CONCLUSIONS}

The present study evaluated the effect of foliar applications of $\mathrm{CaCO}_{3}$ residues from the cement industry on the concentration of phenolic compounds in Shiraz grapes. The results demonstrate that foliar applications of $\mathrm{CaCO}_{3} \mathrm{R}$ increase grape yield and modify the concentration of ions that regulate stomatal closure in the treated vines. Furthermore, the increase in phenolic compound concentration in grapes from treated vines suggests that $\mathrm{CaCO}_{3} \mathrm{R}$ activates the expression of genes involved in the synthesis of ABA or jasmonic acid. Finally, the use of $\mathrm{CaCO}_{3}$ residues from the cement industry offers an effective and economical alternative to increase total phenolic compounds, including anthocyanins, in wine grapes.

\section{LITERATURE CITED}

Abdel-Salam, M.M. \& Hassan, M.A.M., 2015. Effect of $\mathrm{CaCl}_{2}$ sprays on anthocyanins, pectin and phenolic acids fractionation in berry skin of two red grape (Vitis vinifera L.) cultivars during ripening. Int. J. Acad. Res. 7(1), 159-167.

Alonso, R., Berli, F.J., Fontana, A., Piccoli, P. \& Bottini, R., 2016. Malbec grape (Vitis vinifera L.) responses to the environment: Berry phenolics as influenced by solar UV-B, water deficit and sprayed abscisic acid. Plant Physiol. Biochem. 109, 84-90.

Al-Qurashi, A.D. \& Awad, A., 2013. Effect of pre-harvest calcium chloride and ethanol spray on quality of 'El-Bayadi' table grapes during storage. Vitis 52(2), 61-67.

Anbu, P., Kang, C.H., Shin, Y.J. \& So, J.S., 2016. Formation of calcium carbonate mineral by bacteria and its multiple applications. Springer Plus $5(1), 1-26$.

Andrés, Z., Pérez-Hormanche, J., Leidi, E.O., Schlücking, K., Steinhorst, L., McLachlan, D.H., Schumacher, K., Hetherington, A.M., Kudla, J., Cubero, B. \& Pardo, J.M., 2014. Control of vacuolar dynamics and regulation of stomatal aperture by tonoplast potassium uptake. Proc. Natl Acad. Sci. U. S. A. 111(17), E1806-E1814.

Berli, F.J., Fanzone, M., Piccoli, P. \& Bottini, R., 2011. Solar UV-B and $\mathrm{ABA}$ are involved in phenol metabolism of Vitis vinifera $\mathrm{L}$. increasing biosynthesis of berry skin polyphenols. J. Agr. Food Chem. 59(9), 48744884 .

Boss, P.K., Davies, C. \& Robinson, S.P., 1996. Analysis of the expression of anthocyanin pathway genes in developing Vitis vinifera L. cv 'Shiraz' grape berries and the implications for pathway regulation. Plant Physiol. 111(4), 1059-1066.

Coelho de Souza-Leaño, P., Coelho-Lima, M.A., Días-Costa, J.P. \& Gomesda Trindade, D.C., 2014. Abscisic acid and ethephon for improving red color and quality of crimson seedless grapes grown in a tropical region. Am. J. Enol. Viticult. 66(1), 37-45.

De-la-Hera-Orts, M.L., Martínez-Cutillas, A., López-Roca, J.M. \& GómezPlaza, E., 2005. Effect on moderate irrigation on grape composition during ripening. Span. J. Agric. Res. 3(3), 352-361.

Ferrandino, A. \& Lovisolo, C., 2014. Abiotic stress effects on grapevine (Vitis vinifera L.): Focus on abscisic acid-mediated consequences on secondary metabolism and berry quality. Environ. Exp. Bot. 103, 138-147.
He, F., He, J.J., Pan, Q.H. \& Duan, C.Q., 2010. Mass-spectrometry evidence confirming the presence of pelargonidin-3-O-glucoside in the berry skins of Cabernet Sauvignon and Pinot Noir (Vitis vinifera L.). Aust. J. Grape Wine Res. 16, 464-468.

Jia, H., Jiu, S., Zhang, Ch., Wang, Ch., Tariq, P., Liu, Z., Wang, B., Cui, L. \& Fang, J., 2016. Abscisic acid and sucrose regulate tomato and strawberry fruit ripening through the abscisic acid-stress-ripening transcription factor. Plant Biotechnol. J. 14(10), 2045-2065.

Kiselev, K.V., Dubrovina, A.S., Shumakova, O.A., Karetin, Y.A. \& Manyakhin, A.Y., 2013. Structure and expression profiling of a novel calcium-dependent protein kinase gene, CDPK3a, in leaves, stems, grapes, and cell cultures of wild-growing grapevine Vitis amurensis Rupr. Plant Cell Rep. 32, 431-442.

Koyama, R., Marinho de Assis, A., Yamamoto, L.Y., Borges, W.F. \& Borges, R.S., 2014. Exogenous abscisic acid increases the anthocyanin concentration of berry and juice from 'Isabel' grapes (Vitis labrusca L.). HortScience 49(4), 460-464.

Kyraleou, M., Kallithraka, S., Theodorou, N., Teissedre, P.L., Kotseridis, Y. \& Kondouras, S., 2017. Changes in tannin composition of Syrah grape skins and seeds during fruit ripening under contrasting water conditions. Molecules 22, 1453.

Lacampagne, S., Gagné, S. \& Gény, L., 2010. Involvement of abscisic acid in controlling the proanthocyanidin biosynthesis pathway in grape skin: New elements regarding the regulation of tannin composition and leucoanthocyanidin reductase (LAR) and anthocyanidin reductase (ANR) activities and expression. J. Plant Growth Regul. 29(1), 81-90.

López-Lefebre, L.R., Rivero, R.M., García, P.C., Sánchez, E., Ruiz, J.M. \& Romero, L., 2001. Effect of calcium on mineral nutrient uptake and growth of tobacco. J. Sci. Food Agric. 81(4), 1334-1338.

Luan, L.Y., Zhang, Z.W., Xi, Z.M., Huo, S.S. \& Ma, L.N., 2014. Comparing the effects of exogenous abscisic acid on the phenolic composition of 'Yan' and 'Cabernet Sauvignon' (Vitis vinifera L.) wines. Eur. Food Res Technol. 239(2), 203-213.

Martins, V., García, A., Costa, C., Sottomayor, M. \& Gerós, H., 2018. Calcium- and hormone-driven regulation of secondary metabolism and cell wall enzymes in grape berry cells. J. Plant Physiol. 231, 57-67.

Mikiciuk, G., Mikiciuk, M., Możdżer, E., Statklewicz, M. \& Chylewska, U., 2015. The effects of foliar nutrition with UnCa fertilizers on the chemical composition of leaves and fruits of sweet cherries. J. Ecol. Eng. 16(2), 116119 .

Nogales-Bueno, J., Hernández-Hierro, J.M., Rodríguez-Pulido, F.J. \& Heredia, F.J., 2013. Determination of technological maturity of grapes and total phenolic compounds of grape skin in red and white cultivars during ripening by near infrared hyperspectral image: A preliminary approach. Food Chem. 221, 1685-1690.

OIV (International Organisation of Vine and Wine). 2017. Compendium of international methods of wine and musts analysis. Rue d'Aguesseau-75008 Paris. Online: http://www.oiv.int/en/technical-standards-and-documents/ methods-of analysis/compendium-of-international-methods-of-analysis-ofwines-and-musts-2-vol [accessed 15 July 2017).

Olivares, D., Contreras, C., Muñoz, V., Rivera, S., González-Agüero, M., Retamales, J. \& Defilippi, B.G., 2017. Relationships among color development, anthocyanins and pigment-related gene expression in 'Crimson seedless' grapes with abscisic acid and sucrose. Plant Physiol. Biochem. 115, 286-297.

Oliveira, S.R., Gomes-Neto, J.A., Nóbrega, J.A. \& Jones, B.T., 2009. Determination of macro-and micronutrients in plant leaves by high resolution continuum source flame atomic absorption spectrometry combining instrumental and ample preparation strategies. Spectrochim. Acta B 65(4), 316-320. 
Ornelas-Paz, J.J., Meza, M.B., Obenland, D., Rodrígez-Friscia, K., Jain, A., Thornton, S. \& Prakash, A., 2017. Effect of phytosanitary irradiation on the postharvest quality of seedless kishu mandarins (Citrus kinokuni mukaku kishu). Food Chem. 230, 712-720.

Peppi, M.C., Fidelibus, M.W. \& Dokoozlian, N., 2006. Abscisic acid applications timing and concentration affect firmness, pigmentation, and color of 'Flame Seedless' grapes. HortScience 41(6), 1440-1445.

Prasad, B., Dimri, D.C. \& Bora, L., 2015. Effect of pre-harvest foliar spray of calcium and potassium on fruit quality of pear cv. Pathernakh. Sci. Res. Essays 10(11), 376-380.

Ranty, B., Aldon, D., Cotelle, V., Galaud, J.P., Thuleau, P. \& Mazars. C., 2016. Calcium sensors as key hub in plant responses to biotic and abiotic stresses. Front. Plant Sci. 7, 1-7.

Ruiz, L.P., Atkinson, C.J. \& Mansfield, T.A., 1993. Calcium in the xylem and its influence on the behavior of stoma. Phil. Trans. R. Soc. B 341, 67-74.

Sabir, A., Yazar, K., Sabir, F., Kara, Z., Yazici, M.A. \& Goksu, N., 2014 Vine growth, yield, berry quality attributes and leaf nutrient content of grapevines as influenced by seaweed extract (Ascophyllum nodosum) and nanosize fertilizer pulverizations. Sci. Hortic. 175, 1-8.

Santiago, W.E., Dos-Reis-Tinini, R.C., Augustos-De-Oliveira, R. \& Teruel, B.J., 2013. Partial dehydration of 'Niagara Rosada' grapes (Vitis labrusca L.) targeting increased concentration of phenolic compounds and soluble solids. Afr. J. Biotechnol. 12, 6474-6479.

Singh, S.P., Saini, M.K., Singh. J., Pongener, A. \& Sidhu, G.S., 2014 Preharvest applications of abscisic acid promotes anthocyanins accumulation in pericarp of litchi fruit without adversely affecting postharvest quality. Postharvest Biol. Tech. 96, 14-22.

Squeo, G., Silletti, R., Summo, C., Paradiso, V.M., Pasqualone, A. \& Caponio, F., 2016. Influence of calcium carbonate on extraction yield and quality of extra virgin oil from olive (Olea europaea L. cv. Coratina). Food Chem. 209, 65-71.

Taurino, M., Ingrosso, I., D'amico, L., De Domenico, S., Nicoletti, I., Corradini, D., Santino, A. \& Giovinazzo, G., 2015. Jasmonates elicit different sets of stilbenes in Vitis vinifera cv. Negramaro cell cultures. SpringerPlus 4(49), 2-11.

Vandelle, E., Vannozzi, A., Wong, D., Danzi, D., Digby, A.M., Dal Santo, S. \& Astegno, A., 2018. Identification, characterization, and expression analysis of calmodulin and calmodulin-like genes in grapevine (Vitis vinifera) reveal likely roles in stress responses. Plant Physiol. Biochem. $129,221-237$.
Villalobos-González, L., Peña-Neira, A., Ibáñez, F. \& Pastenes, C., 2016. Long-term effects of abscisic acid (ABA) on the grape berry phenylpropanoid pathway: Gene expression and metabolite content. Plant Physiol. Biochem. 105, 213-223.

Vishwakarma, K., Upadhyay, N., Kumar, N., Yadav, G., Singh, J., Mishra, R.K., Kumar, V., Verma, R., Upadhyay, R.G., Pandey, M. \& Sharma, S., 2017. Abscisic acid signaling and abiotic stress tolerance in plants: A review on current knowledge and future prospects. Front. Plant Sci. 8(161), 1-12.

Wang, J., Wang, S., Liu, G., Edwards, E. J., Duan, W., Li, S. \& Wang, L., 2016. The synthesis and accumulation of resveratrol are associated with veraison and abscisic acid concentration in Beihong (Vitis vinifera $\times$ Vitis amurensis) berry skin. Front. Plant Sci. 7, 1-11.

Wang, L., Ma, L., Xi, H., Duan, W., Wang, J. \& Li, Sh., 2013. Individual and combined effects of $\mathrm{CaCl} 2$ and UV-C on the biosynthesis of resveratrol in grape leaves and berry skins. J. Agric. Food Chem. 61(29), 7135-7141.

Wang, Y., Xie, X. \& Long, L.E., 2014. The effect of postharvest calcium application in hydro-cooling water on tissue calcium content, biochemical changes, and quality attributes of sweet cherry fruit. Food Chem. 160, 23 30 .

Xu, W., Peng, H., Yang, T., Whitaker, B., Huang, L., Sun, J. \& Chen, P., 2014 Effect of calcium on strawberry fruit flavonoid pathway gene expression and anthocyanin accumulation. Plant Physiol. Biochem. 82, 289-298.

Yamamoto, L.Y., Marinho de Asis, A., Roberto, S.R., Bovolenta, Y.R., Nixdorf, S.N., García-Romero, E., Gómez-Alonso, S. \& HermosínGutiérrez, I., 2015. Application of abscisic acid ( $S$-ABA) to cv. Isabel grapes (Vitis vinifera $\mathrm{x}$ Vitis labrusca) for color improvement: Effects on color, phenolic composition and antioxidant capacity of their grape juice. Food Res. Int. 77(3), 572-583.

Yang, T., Peng, H., Whitaker, B.D. \& Conway, W.S., 2012. Characterization of calcium/calmodulin-regulated SR/CAMTA gene family during tomato fruit development and ripening. Plant Biol. 12(19), 2-13.

Zou, J.J., Li, X.D., Ratnasekera, D., Wang, C., Liu, W.X., Song, L.F., Zhang, W.Z. \& Wu, W.H., 2015. Arabidopsis calcium-dependent protein kinases 8 and catalase 3 function in abscisic acid-mediated signaling and $\mathrm{H}_{2} \mathrm{O}_{2}$ homeostasis in stomatal guard cells under drought stress. Plant Cell $27(5), 1445-1460$. 